Article

\title{
Agroecology in Europe: Research, Education, Collective Action Networks, and Alternative Food Systems
}

\author{
Alexander Wezel * ID, Julia Goette, Elisabeth Lagneaux, Gloria Passuello, Erica Reisman, \\ Christophe Rodier and Grégoire Turpin
}

ISARA Lyon, Department of Agroecology and Environment, 23 rue Jean Baldassini, 69364 Lyon, France; jgoette@etu.isara.fr (J.G.); elagneaux@etu.isara.fr (E.L.); gpassuello@etu.isara.fr (G.P.); ereisman@etu.isara.fr (E.R.); crodier@etu.isara.fr (C.R.); gturpin@etu.isara.fr (G.T.)

* Correspondence: awezel@isara.fr; Tel.: +33-427-858-584

Received: 22 February 2018; Accepted: 12 April 2018; Published: 17 April 2018

\begin{abstract}
Agroecology is considered with different focus and weight in different parts of the world as a social and political movement, as science, and as practice. Despite its multitude of definitions, agroecology has begun in Europe to develop in different regional, national and continental networks of researchers, practitioners, advocates and movements. However, there is a lack of a comprehensive overview about these different developments and networks. Therefore, this paper attempts to document and provide a mapping of the development of European agroecology in its diverse forms. Through a literature review, interviews, active conference participation, and an extensive internet search we have collected information about the current state and development of agroecology in Europe. Agroecological research and higher education exist more in western and northern Europe, but farm schools and farmer-to-farmer training are also present in other regions. Today a large variety of topics are studied at research institutions. There is an increasing number of bottom-up agroecological initiatives and national or continental networks and movements. Important movements are around food sovereignty, access to land and seeds. Except for France, there are very few concrete policies for agroecology in Europe. Agroecology is increasingly linked to different fields of agri-food systems. This includes Community Supported Agriculture systems, but also agroecological territories, and some examples of labelling products. To amplify agroecology in Europe in the coming years, policy development will be crucial and proponents of agroecology must join forces and work hand-in-hand with the many stakeholders engaged in initiatives to develop more sustainable agriculture and food systems.
\end{abstract}

Keywords: agroecological; agroecology movement; agricultural policy; European agriculture; sustainable agriculture and food systems; teaching and training

\section{Introduction}

The search for sustainable development of agriculture and of food systems is currently being prioritized in many parts of the world. Among the indicators of change are an accelerated development of agroecology to meet the global challenges of food supply, food quality, biodiversity conservation, climate change and social justice. The need to strongly enlarge and develop agroecology in the World, including Europe, is also a major outcome and quest of the international FAO Agroecology Symposium in Rome, held in April 2018 with more than 700 participants, including policy makers, ministers of national governments, civil society organisations, agriculture, food systems and development NGOs, professional and academia. 
Since the term 'agroecology' was first used in 1928 [1], its meaning has evolved and expanded, keeping pace as institutional understanding of agriculture has become more and more sophisticated [2]. Though initially a purely scientific discipline, agroecology has also come to mean a set of more ecologically sound agricultural practices and also a movement that incorporates food sovereignty, social justice, and the preservation of indigenous knowledge.

The term 'agroecology' can also take different meanings in different parts of the world [2], and even within Europe, different countries have their own meaning of 'agroecology' according to their own national contexts. For example, in Germany, agroecology stays mainly true to its pure scientific roots and largely operates within the realms of plant sciences, ecology and zoology, while in Italy it is much closer connected to the organic farming movement [3]. In France, there exists a substantial representation from both the practice and science sides of agroecology, though the movement is present as well. Historically throughout Europe, there has been a pattern of science and practitioners largely operating within their own realms [4], and more recently social movements in agroecology have developed as well, e.g., the European Coordination of La Via Campesina [5] and Friends of the Earth Europe [6]. In this paper we refer to the definition given by the Association of Agroecology Europe (www.agroecology-europe.org): 'Agroecology is considered jointly as a science, a practice and a social movement. It encompasses the whole food system from the soil to the organization of human societies. It is value-laden and based on core principles. As a science, it gives priority to action research, holistic and participatory approaches, and transdisciplinarity including different knowledge systems. As a practice, it is based on sustainable use of local renewable resources, local farmers' knowledge and priorities, wise use of biodiversity to provide ecosystem services and resilience, and solutions that provide multiple benefits (environmental, economic, social) from local to global. As a movement, it defends smallholders and family farming, farmers and rural communities, food sovereignty, local and short marketing chains, diversity of indigenous seeds and breeds, healthy and quality food'.

Even with its multitude of definitions across countries, agroecology in Europe has begun to cohere into a continental network of researchers, students, practitioners and advocates. As a testament to this process is the creation of Agroecology Europe, an association that works to promote the agroecological transition in Europe and foster interactions across stakeholders and disciplines [7]. Adding to the momentum that agroecology has been gaining in recent years were also the symposia, forums and gatherings of different types of stakeholders such as the Agroecology in Action Forum in Belgium in 2016 [8], the FAO regional symposium on Agroecology for Sustainable Agriculture and Food Systems in Hungary 2016 [9], the Agroecology Europe Forum in France in 2017 [10], and the FAO symposium on Agroecology for Food Security and Nutrition in Italy 2014 [11], the first symposium on agroecology ever hosted and coordinated by the FAO.

Despite its expansion in both academic and non-academic circles, and the work of Agroecology Europe that is trying to bring it all together, there has not yet been a publication that more comprehensively maps agroecology in its different guises across Europe. In this paper, we attempt to do this by researching how agroecology exists in Europe and synthesising this information by analysing research institutions, research topics, education and training programmes, social movements and networks, policies, and major agri-food system-related agroecology topics.

\section{Information Collection}

Different methods were used to obtain a comprehensive overview and review of agroecology in Europe. The work was carried out between September 2017 and February 2018. A literature review and intensive internet research have been conducted. The review was mainly done with the keywords 'agroecology' and 'agroecological', combined with the keywords related to the sections and subsections of this paper: research and education, collective action, agriculture and alternative food systems. The keywords were searched in English, French, Spanish, Italian and German. The internet research was carried out about the movements and networks, schools and universities, research institutions, research topics, and projects related to agroecology in Europe. Research institutions were selected that 
have 'agroecology' in department or research group/unit names, or also considered when mentioned by the interviewees or participants of the Agroecology Forum (see below). Identification of main research topics was based on the analysis of [4] that carried out a specific internet research using Scopus database, the Scopus field AFFILORG and CorText Manager software to identify actors, affiliations and research topics, which was complemented by own internet research and information from interviews. Education and programmes were documented that either contain agroecology in their titles, or have agroecology as a major component in their courses.

The NGOs and movements that were included were identified with the participants to the Agroecology Europe Forum (see below) and by a keyword research on European organisations working on 'agroecology', 'food sovereignty', 'community supported agriculture', 'network', 'land access', and 'urban agriculture'.

An important source of information was the first Agroecology Europe Forum, which took place in Lyon, France, in October 2017 (www.agroecology-europe.org/agroecology-forum-2017). It brought together more than 310 proponents of agroecology, from farmers to academics, from companies to social movements, and allowed a useful overview and insight into topics of agroecological research and movements across Europe, as well as current debates within the field. For all 23 workshops and sessions, summaries were written and also used for the present work. In addition, participants' talks, abstracts, and posters linked to their research, activity or propositions were a very useful source to map agroecology in Europe.

Finally, during the Agroecology Europe Forum, ten interviews were conducted with speakers and participants. The choice of the persons to interview was done in order to prioritise the countries that were not addressed in the talks of the forum, and to extend the picture of agroecology in Europe. It included persons from Finland, Hungary, Austria, Belgium, United Kingdom, Italy, France, representing NGOs, movements, farmers and universities. These interviews were about 10 to $15 \mathrm{~min}$ long because of short-time availability of Forum attendees and to get a quick overview for different countries, which was later complemented by internet and literature research. The interviewees were asked about the movements, projects and education programmes related to agroecology that are happening in their countries, and about their personal involvement in these initiatives. In addition, seven persons were interviewed about agroecology in their country before and after the Forum. This included mainly persons from different universities in the Czech Republic, Poland, Greece, Germany, Italy, Spain, the United Kingdom and Ireland.

\section{Research and Education in Agroecology in Europe}

Research and education are major components to agroecology in Europe and are often a bridge between its manifestations of 'science' and 'practice'. Not only is there a vast array of topics studied and taught under the agroecology banner, but the forms taken by research and education also span a great range, from the ivory tower to the farm, and are enumerated in the next sections. At one end, there is what we have labelled as 'research institutions' and their topics, followed by 'academia'. Academia is distinct from research institutions in that it offers educational degrees in agroecology, but both academia and research institutions generate agroecological science (as do farmers themselves with field experiments-but this is not analysed in this section). Within these, there are some that focus on agroecology exclusively, some that have agroecology as a subsection of their divisions, and others that host agroecology meta-programmes that bridge different divisions or even different research areas. One type of research utilised by these institutions is Participatory Action Research (PAR). With PAR, the subjects of the research are integral in shaping the research process itself, and this approach is often used for agroecological research because of its transdisciplinary approach. Finally, at the purely practical, on-the-ground end of the spectrum are farm schools. Rather than focusing on generating formal science, these institutions are geared towards training farmers in agroecological farming practices. 


\subsection{Research Institutions}

An increasing number of research institutions use the term 'agroecology' in their designation of institutes, departments, chairs and research groups (Table 1). While most of them are more historically rooted in agronomy and ecology, more recently there have been groups and departments working more on economic and social aspects, including agroecology. In this section we will mention some of these institutes and departments which deal more specifically with agroecology. It should be noted that other research institutions in Europe deal with agroecology, but without designating it clearly in its descriptions and affiliations, and thus they are not included in this section (but they are considered in the research topic section).

Table 1. List of research institutions designating agroecology in their institution with departments, institutes, and research groups.

\begin{tabular}{|c|c|}
\hline Country & Institution \\
\hline Belgium & $\begin{array}{l}\text { GIRAF (Interdisciplinary Agroecology Research Group of the FNRS (Belgian National Scientific } \\
\text { Research Foundation)) }\end{array}$ \\
\hline Bulgaria & Faculty of Plant Protection and Agroecology, Agricultural University of Plovdiv \\
\hline Croatia & Department of Agroecology, University of Osijek \\
\hline Denmark & Department of Agroecology, Aarhus University \\
\hline France & INRA (National Institute for Agricultural Research) \\
\hline France & $\begin{array}{l}\text { Agroecology joint research unit (UMR Agroécologie), INRA Dijon, CNRS (National Center For } \\
\text { Scientific Research) Dijon, AgroSup (National Superior Institute for Agronomic sciences, Food and } \\
\text { Environment) Dijon, University of Burgundy, Dijon }\end{array}$ \\
\hline France & $\begin{array}{l}\text { Research unit Agroecology and Sustainable Intensification of Annual Crops, CIRAD } \\
\text { (Agricultural Research for Development) }\end{array}$ \\
\hline France & Department of Agroecology and Environment, ISARA-Lyon \\
\hline France & Leguminosae, Plant Ecophysiology, Agroecology research unit (LEVA), ESA Angers \\
\hline Germany & Agroecology Group, University of Göttingen \\
\hline Germany & $\begin{array}{l}\text { Agroecology in the Tropics and Subtropics group, Institute of Agricultural Sciences in the Tropics, } \\
\text { University of Hohenheim }\end{array}$ \\
\hline Germany & $\begin{array}{l}\text { Institute for Agroecology, Organic Farming, Soil Conservation, Plant Nutrition and Landscape } \\
\text { management, Bavarian State Research Centre for Agriculture }\end{array}$ \\
\hline Moldavia & Department of Agroecology and Soil Science, Agricultural State University of Moldavia, Chisinau \\
\hline Netherlands & Wageningen Centre for Agroecology and Systems Analysis, Wageningen University \\
\hline Poland & Central Laboratory of Agroecology, University of Life Sciences of Lublin \\
\hline Poland & Department of Agroecology, University of Rzeszów \\
\hline Slovakia & Agroecology Research Institute, Slovak Agricultural Research Centre, Michalovce \\
\hline Spain & Chair on Agroecology and Food Systems, University of Vic \\
\hline Switzerland & Agroecology and Environment research division, Agroscope, Reckenholz \\
\hline UK & Agroecology Group, James Hutton Institute, Dundee \\
\hline UK & Agroecology Department, Rothamsted Research, Harpenden \\
\hline UK & Centre for Agroecology Water and Resilience, Coventry University \\
\hline Ukraine & $\begin{array}{l}\text { Institute of Agroecology and Land Management, National University of Water and Environmental } \\
\text { Engineering, Rivne }\end{array}$ \\
\hline
\end{tabular}


In Scandinavia, the Department of Agroecology at Aarhus University, which has a large number of researchers, carries out research on the interactions between climate, soil, plants, animals and humans in agroecosystems for the advancement of health, sustainability and eco-friendly production of food, feed, energy and bio-based products. In Germany, two universities have agroecology research groups: the University of Göttingen and the University of Hohenheim. Whereas the group at the University of Göttingen deals mainly with biodiversity, pollination and biological pest control in agroecosystems, the group at the University of Hohenheim has a focus on the development of tropical land use systems that optimise beneficial biotic interactions, and reduce antagonistic ones, in agroecosystems. Other institutions in Germany that deal with agroecology are a Federal State Research Centre and two private research institutes (Table 1). In Switzerland, there is the Agroecology and Environment research division of Agroscope. Their research topics vary from water and soil protection, soil fertility, plant-soil interactions, to agricultural landscapes and biodiversity.

An important and large institution dealing with agroecology research in France is INRA (National Institute for Agricultural Research, Paris, France). Although they do not have special departments with the agroecology designation, they are leaders in a few joint research units. These joint research units (UMR-Unité Mixte de Recherche) are a specific inter-institutional structure for research in France consisting in most cases of researchers from different institutions. A first joint research unit, called 'Agroecology', consists of researchers from INRA Dijon, CNRS Dijon, AgroSup Dijon, and the University of Burgundy, Dijon. Another joint research unit is 'Agroecologies, Innovations and Ruralities', a cooperation of INRA, ENSAT and INP at Toulouse. Finally, the 'Health and Agroecology of Vineyards' joint research unit combines researchers from INRA Bordeaux, Bordeaux Sciences Agro, Institute of Vine \& Wine Science, Bordeaux. Another French institution dealing with agroecology, mainly in the tropics and subtropics, is CIRAD (Agricultural Research for Development). They have a special research unit 'Agroecology and Sustainable Intensification of Annual Crops'. Also, ISARA-Lyon, an institute for higher education and research, has a department 'Agroecology and Environment' that deals with different research topics in agroecology, and interacts with the Social Science department in agroecology and the food systems research. A similar institute for higher education is ESA Angers, having a research unit 'Leguminosae, Plant Ecophysiology, Agroecology'.

In the Netherlands, Wageningen University has the 'Centre for Agroecology and Systems Analysis'. Key research topics there are global food security, respectful animal production, competing claims on natural resources, bio-based economy, nutrient and water management, viability of rural areas, and climate change and climate variability.

In Belgium there exists the GIRAF, the 'Interdisciplinary Agroecology Research Group of the FNRS' (Belgian National Scientific Research Foundation). It consists of scientists from different Belgian institutions and universities that study different topics in agroecology.

In the UK, the 'Agroecology' group of the James Hutton Institute researches the scientific basis for development of sustainable croplands. The 'Agroecology' department at Rothamsted Research has its focus on understanding the ecological mechanisms that deliver sustainable crop production (ecology of pests and pollinators, above- and below-ground functional biodiversity, weed ecology). Finally, the 'Centre for Agroecology Water and Resilience' at Coventry University is driving research on the understanding and development of resilient food and water systems.

In the more southern Europe region, we find 'Agroecologiki' in Greece. It is an organisation that, among other activities, conducts applied research and development on agroecology and sustainable food production systems.

In Eastern Europe, fewer universities have departments, institutes or research groups designated to Agroecology. One each can be found in Bulgaria, Croatia, the Czech Republic, Lithuania, Slovakia, Ukraine, and Bosnia and Herzegovina. In Bosnia and Herzegovina, the Institute of 'Agroecology and Soil' at the University of Banja Luka researches topics around soil, plants and environmental protection, and land reclamation. In Poland, agroecology is designated at the University of Lublin and the University of Rzeszów. 
It is also true that other research institutions in Europe deal with agroecology, but without designating it in its descriptions or affiliations. Among them are AgroParisTech, France; University of Natural Resources and Life Sciences, Vienna, Austria; University of Kassel-Witzenhausen, Germany; SLU, Sweden; NMBU, Norway; University of Helsinki, Finland; Research Institute of Organic Agriculture (FiBL, Frick), Switzerland; University of Liege, University of Gembloux, Catholic University of Leuven, Belgium; University of South Bohemia, Czech Republic; in Italy the Sant'Anna, School of Advanced Studies, Pisa, and University of Gastronomic Sciences (UNISG, Bra, Italy), and several universities in Spain: International University of Andalucia, University of Cordoba, Pablo de Olavide University, Sevilla, University of Barcelona. In addition, there are many organic research institutions in different countries in Europe whose research falls under the umbrella of agroecology.

Although from above it is apparent that a large number of institutions in Europe carry out research in agroecology, Ref. [4] analysed the co-authors of joint publications in agroecology and found that in Europe, stakeholders from agroecology research tend to collaborate very little, indicated by only relatively few joint publications involving at least two institutions from different countries. An exception is stakeholders from organizations that work on questions around social movements within agroecology, which tend to collaborate more. However, even when there is collaboration, it is not guaranteed that everyone shares the same notion of agroecology, and inversely, sharing the same notion of agroecology does not ensure collaboration.

\subsection{Research Topics}

There are a myriad of topics that today can fall under agroecological research, and they range from the field scale to the food systems scale. Some have already been mentioned before in the research institutions section. The current key topics that are researched at different research institutions are summarized in Table 2.

Table 2. Major current agroecology research topics and keywords.

\begin{tabular}{cl}
\hline Topic & Subtopics and Key Words \\
\hline \multirow{2}{*}{ Soil } & Soil fertility and soil quality \\
& Soil biodiversity \\
& Soil structure \\
\hline \multirow{2}{*}{ Water } & Irrigation strategies \\
& Water quality \\
\hline \multirow{3}{*}{ Ecosystem services } & Biodiversity conservation \\
& Pest regulation \\
& Greenhouse gas regulation \\
& Nutrient cycling \\
\hline & Agroecological practices \\
& Conservation agriculture \\
& No tillage \\
& Cover crops \\
& Fertilization \\
& Biological control \\
& Perennial crops \\
& Agroforestry \\
& Grassland management \\
& Seeds \\
& Climate change adaptation \\
\hline \multirow{2}{*}{ Agroecosystems practices } & Management \\
& Sustainability \\
& Animal health \\
& Crop heath \\
& Quality food \\
\hline \multirow{2}{*}{ Health } &
\end{tabular}


Table 2. Cont.

\begin{tabular}{cl}
\hline \multicolumn{1}{c}{ Topic } & Subtopics and Key Words \\
\hline & Rural development \\
& Food sovereignty \\
& Labour \\
& Farm decline \\
Socio-Economics & Stakeholder networks \\
& Knowledge production and exchange \\
& Transition to agroecology \\
& Local food systems \\
& Community supported agriculture \\
& Food labels \\
Food system & Participatory guarantee systems \\
& Transition to agroecological food systems \\
\hline
\end{tabular}

Nicot [4] also catalogued the terminologies used for agroecology research in recent years. Popular research topics included soil microbial communities and soil structure, irrigation strategies, species richness, agricultural intensification, greenhouse gases, tillage systems, and conservation agriculture. The agroecological literature found by [4] slants strongly towards the agronomy side of agroecology, but there are other research initiatives looking at the other sides, such as rural development, knowledge systems and transition to agroecology (for some examples see [12]).

The broad multifaceted nature of agroecology itself presents a challenge to represent the entirety of its body of research. Regardless of an exact tally of agroecology research topics in Europe, it can be said that the numerous research institutions across Europe are tackling agroecological research from many angles.

\subsection{Academia}

In order to train the next generations of agroecologists, numerous institutions have created education programmes in agroecology (Table 3). The commonalities between these education programmes are that many of them are based on case studies or case projects. The Master's programmes are usually four semesters long, the last one usually being a master thesis. Many of the master programmes are international and organised by a consortium of universities from different countries. Some of these programmes are run as double degrees with two or more universities involved. Moving from one university to another allows the student to have a diversified academic experience of agroecology. Moreover, the programmes gather a diversity of nationalities and backgrounds, especially for those taught in English. Geographically, these programmes are mainly located in the northern and western parts of Europe: Norway, Sweden, Germany, France, Belgium, the Netherlands and Spain. Only a few universities in the east or southeast parts of Europe are involved in these programmes. The main language of agroecology education is English, even in countries where English is not the official language. Besides the Master's programmes, there are also some Bachelors, PhDs, certificates, and a virtual university in agroecology.

Some agroecology programmes are part of plant sciences departments or rural development faculties. Thus, the approach to agroecology may differ depending on the inner structures of universities and which topics they put forward in agroecology. Consequently, there are differences in the leading contents of a degree in agroecology. Some programmes, for example, focus more on food sovereignty and rural development, others more on sustainable agricultural production systems and agroecosystems management. 
Table 3. Academic agroecology programmes in Europe.

\begin{tabular}{|c|c|c|c|}
\hline Level & Name & Universities and Institutions & Language \\
\hline Master & $\begin{array}{l}\text { Agroecology and Food Security } \\
\text { (from Sept. } 2018 \text { onwards } \\
\text { Agroecology, Water and } \\
\text { Food Sovereignty) }\end{array}$ & University of Coventry (UK) & English \\
\hline Master & $\begin{array}{c}\text { European Master of Agroecology } \\
\text { (double degree) }\end{array}$ & $\begin{array}{l}\text { ISARA, Lyon (France), Norwegian University of } \\
\text { Life Science, NMBU (Norway), }\end{array}$ & English \\
\hline Master & $\begin{array}{l}\text { Agroecology-Organic Agriculture } \\
\text { (double degree) }\end{array}$ & $\begin{array}{l}\text { ISARA, Lyon (France), Wageningen University } \\
\text { (The Netherlands), }\end{array}$ & English \\
\hline Master & Agroecology & $\begin{array}{c}\text { Norwegian University of Life Science, NMBU, } \\
\text { Aas (Norway) }\end{array}$ & English \\
\hline Master & Organic Agriculture & Wageningen University (The Netherlands) & English \\
\hline Master & $\begin{array}{c}\text { Organic Agriculture and Food } \\
\text { Systems } \\
\text { (double degree) }\end{array}$ & $\begin{array}{c}\text { Aarhus University (Denmark), University of } \\
\text { Hohenheim (Germany), BOKU (Austria), } \\
\text { Warsaw University (Poland), ISARA, } \\
\text { Lyon (France) }\end{array}$ & English \\
\hline Master & $\begin{array}{l}\text { Sustainable International } \\
\text { Agriculture }\end{array}$ & $\begin{array}{l}\text { University of Kassel-Witzenhausen (Germany) } \\
\text { and University of Göttingen (Germany) }\end{array}$ & English \\
\hline Master & Agroecology & $\begin{array}{l}\text { Swedish University of Agricultural Sciences } \\
\text { (Sweden) }\end{array}$ & English \\
\hline Master & Agroecology & Harper Adams University (United Kingdom) & English \\
\hline Master & $\begin{array}{l}\text { Master Interuniversitaire en } \\
\text { Agroécologie }\end{array}$ & $\begin{array}{c}\text { University of Gembloux (Belgium), } \\
\text { Free University of Brussels (Belgium), } \\
\text { University of Paris-Saclay, } \\
\text { AgroParisTech (France) }\end{array}$ & French \\
\hline Master & $\begin{array}{l}\text { Agroecologia: Un Enfoque para la } \\
\text { Sustentabilidad Rural }\end{array}$ & $\begin{array}{c}\text { International University of Andalusia (Spain), } \\
\text { Pablo de Olavide University (Spain), } \\
\text { University of Cordoba (Spain) }\end{array}$ & Spanish \\
\hline $\begin{array}{l}\text { Bachelor, } \\
\text { Master }\end{array}$ & Agroecology & University of Zagreb (Croatia) & Croatian \\
\hline $\begin{array}{l}\text { Bachelor, } \\
\text { Master }\end{array}$ & AgroecologyAgroecology & Mendel University, Brno (Czech Republic) & Czech \\
\hline $\begin{array}{l}\text { Bachelor, } \\
\text { Master }\end{array}$ & $\begin{array}{l}\text { Study in Agricultural Ecosystems } \\
\text { and Agroecology }\end{array}$ & University of South Bohemia (Czech Republic) & Czech \\
\hline Summer School & $\begin{array}{l}\text { International Summer School in } \\
\text { Agroecology }\end{array}$ & $\begin{array}{l}\text { ENSFEA and University of Toulouse (France), } \\
\text { SLU (Sweden), Pablo de Olavide University } \\
\text { (Spain), University of Liège (Belgium) }\end{array}$ & English \\
\hline Summer School & Agroecology Summer School & ISARA, Lyon (France) & English \\
\hline Summer School & $\begin{array}{l}\text { Agroecology: small-scale and } \\
\text { sustainable cultivation in theory } \\
\text { and practise }\end{array}$ & Karlskoga Folkhögskola (Sweden) & Swedish \\
\hline Summer School & Agroecology and animal production & $\begin{array}{l}\text { Agreenium (France), Wageningen University } \\
\text { (The Netherlands) }\end{array}$ & English \\
\hline Ph.D. & Agroecology & Aarhus University (Denmark) & English \\
\hline Ph.D. & Agroecology & University of Coventry (UK) & English \\
\hline $\begin{array}{l}\text { Inter-University } \\
\text { Certificate }\end{array}$ & $\begin{array}{l}\text { Agroécologie et transition vers des } \\
\text { systèmes alimentaires durables }\end{array}$ & $\begin{array}{l}\text { Université catholique de Louvain, l'Université de } \\
\text { Liège, l'Université libre de Bruxelles }\end{array}$ & French \\
\hline MOOC & Université Virtuelle d'Agroécologie & INRA, Agreenium, ISARA (France) & French \\
\hline
\end{tabular}

\subsection{Farm Schools and Farmer-to-Farmer Training}

Research and education does not just belong to higher education, there are many institutions, organizations or networks that specifically offer teaching and training on how to practice agroecology on the farm level or how to develop food systems. Some organizations emphasize the connection between the 'movement' and 'practice' components of agroecology by facilitating networking and knowledge-sharing between agroecology practitioners. The European Agroecology Knowledge Exchange Network [13] is one such organization that aggregates different organizations in grassroots 
agroecology training and learning from across Europe, thus facilitating the transfer of agroecology knowledge. The network intends to develop its activities around: (1) focusing on horizontal learning approaches; (2) the dynamics between political and practical training and learning; and (3) the specificity of place in training and learning; and (4) building local, regional and global networks for mutual support and resourcing.

Another kind of farmer-to-farmer networking and knowledge-sharing are one-off training or networks events, such as the 'CSAct! Farmer-to-Farmer Training Program' [14]. These five-day trainings are organized by Urgenci to help CSA farmers to network and learn from each other in all areas of farming, including soil fertility to farm finances.

There are also different farmer training centres in Europe that have shorter- or longer-period training in agroecology. Some examples from France, Spain and Belgium can be found in Table 4 . Among them is Agrotopia, an agroecology training and research centre in Belgium that has a six-level training course where people can simply learn about agronomy for the first level, or choose to complete all six levels of the programme in order to become a project coach for further agroecology projects.

Table 4. Examples of training centres with agroecology for farmers or other stakeholders in Belgium, France and Spain.

\begin{tabular}{cc}
\hline Country & Name of Training Centre \\
\hline Belgium & Agrotropia \\
Belgium & Ecole Paysanne Indépendante \\
France & Oasis De Pen An Hoat \\
France & Les Amanins Centre Agroécologique \\
France & Terre \& Humanisme \\
France & Ferme éco-citoyenne de la Bouzigue \\
France & Université Colibris \\
France & Fédération des Associations pour le Développement de l'Emploi Agricole et Rural \\
France & Université Virtuelle d'Agroécologie \\
Spain & Fundación Instituto de Agricultura Ecológica y Sostenible \\
Spain & Centro de Estudios Rurales y de Agricultura Internacional \\
Spain & Multiversidad de Agroecología, Biodiversidad y Culturas \\
\hline
\end{tabular}

But education and research do not need to be so formal with training centres or organizations. Farmers also conduct their own research on their farms year after year, making small adjustments and testing new solutions, and thus adding to their farming and site-specific local knowledge. When one Belgian farmer at the Agroecology Europe Forum was asked which farmers' networks he participates in, he said above all it would just be communicating with his neighbours and colleagues. This is not something that would be evident while researching farmer-to-farmer initiatives, but is nevertheless an important component. So, for every labelled farmer-to-farmer initiative, one can also assume there are dozens more invisible connections between farmer colleagues who exchange knowledge and support.

\section{Collective Action}

\subsection{Political Action and Policy}

Thus far, there has been no clear EU strategy for agroecological practices and sustainable agriculture, and national action plans and political will on this topic still remain both marginal and varied. France was the first country to introduce agroecology into its legislation, and is still the sole country among the $28 \mathrm{EU}$ member states to have set up an explicit 'Agroecological Project for France' strategy in 2012 [15]. The notions of 'agroecological model' and 'agroecological measures' are mentioned in article L1, Section 2 of the 'Code Rural et de la Pêche Maritime' (Rural and Marine Fishery Codex), that defines the objectives of political support for agriculture, food and marine fishery [16]. This law states that 'public policies aim to promote and sustain agroecological production systems, 
including organic production, which combine economic and social performance, particularly through a high level of social, environmental and health protection.' Article L1 II was adopted in October 2014.

Because of this law, 411 Economic and Environmental Interest Groups (GIEE) have been created [17]. These groups are formed at the initiative of farmers who are working together on a common agroecological objective. The goal of these groups is to support the dynamics of farmers towards better economic, social and environmental practices, through a participatory and inclusive strategy.

Another country showing explicit national support to agroecology is the Czech Republic, where in 2015 the Minister of Agriculture announced an increased support to farmers who practice agroecological farming. Concretely, the government uses the second pillar of the CAP to financially encourage farmers to invest in innovative farming methods, and also agroecology-related agri-environment measures ([18], personal communication Moudry).

\subsection{Political Action and Social Movements}

As mentioned in the introduction, agroecology grew from being solely a scientific discipline during the 1930s to becoming a multidisciplinary paradigm by the 1980s, by which time it had already begun to encompass practice, science and a movement/political dimension. This expansion allowed agroecologists to investigate the food system more holistically. In this context, many civil society movements embraced the notion of agroecology, thus charging it with political meaning by proposing it as an alternative to the post-Green Revolution agri-food system.

La Via Campesina (LVC), founded in 1993, was one of the first such movements, and is widely considered to be the most influential, advocating for a change in the current industrial food system. It considers agroecology as 'the answer to how to transform and repair our material reality in a food system and rural world that has been devastated by industrial food production and its so-called Green and Blue Revolutions. We see agroecology as a key form of resistance to an economic system that puts profit before life' [5]. La Via Campesina started as a group of rural farmers in the Global South but later expanded and reached a widespread consensus among other farmer groups, NGOs and Civil Society Organisations (CSOs) across Africa, Asia, Europe, and Latin and North America. In Europe a separate branch, the European Coordination La Via Campesina (ECVC), was created to tackle specifically the issue of food sovereignty and agroecology in Europe. Today, the NGO has 16 national sub-sections [19].

In the late 1990s and later, other movements started adopting the notion of agroecology as a way to both re-establish social justice within the food system and to promote the sustainable production of food while still respecting cultural traditions and natural landscapes. To give some examples, FIAN International, founded in 1986, is a humanitarian organisation with national subsections in over 50 countries and whose mission is to advocate for the right to adequate food and nutrition worldwide [20]. Friends of the Earth Europe is a network of 30 national organisations lobbying for environmental, social, economic and political justice of food systems supported by agroecology [21]. The IFOAM EU Group, the international organic movement with national sections and an overarching European section, can also be categorized here [22]. Additionally, all national movements and networks in organic farming would fall into this category, though they are not listed here. A more recent movement is Cultivate!, an international collective whose goal is to catalyse the transition to healthy food and farming that is rooted in agroecology [23].

Some other NGOs that refer and promote agroecology started as national entities before reaching a European and worldwide scale. For example, Slow Food was founded by a group of activists in Italy in the 1980s, but now the movement is present with national sections in Germany, Switzerland, the UK, the Netherlands, the United States, Japan, Brazil, Kenya and South Korea [24]. Slow Food's 'Ark of Taste' campaign aims to map traditional food products specific to both a territory and a culture in order to preserve the production of traditional food and to support the farmers involved. As the Ark of Taste initiative evolved, it began to recognize products that also save animal and plant breeds at risk for extinction, as well as boost the regional micro-economy, and support family-run or small-scale businesses. This expanded Ark of Taste initiative then became the 'Slow Food Presidia' project, which 
has the aim of protecting biodiversity, territories and traditional knowledge. The total number of Slow Food Presidia that are established and labeled around the world is 530, of which 250 are in Italy [25]. Slow Food Europe clearly points to agroecology to illustrate which agriculture should be further developed [26].

However, a movement does not need to use the term 'agroecology' to still belong to the movement. Interviews with Hungarian participants at the European Agroecology Forum made clear that even though the term 'agroecology' is not widely accepted and/or used in Hungary, there are associations that support agroecology-oriented agriculture in the country, e.g., Kislépték and Butterfly Development. Kislépték's goal is to improve the legal and economic conditions for small-scale, local initiatives that can strengthen the local economy and to promote environmentally low-impact methods of food production and processing, including handicraft production and its market access [27]. The Butterfly Development association promotes a community-based organic agricultural program to spread sustainable developmental models among small village communities, in order to have a positive impact on nutrition, economy and ecology within the villages by implementing community supported agriculture [28].

Another example of agroecological movements are Voedsel Anders (Food Otherwise), a network of different types of stakeholders in the Netherlands and Belgium engaged in building fair and sustainable food systems [29]. Further examples from the Netherlands, such as Bionext and Toekomstboeren, are stated in [30].

\subsection{Movements for Access to Land and Seeds}

Land access is a key obstacle for the development of agroecology in Europe. Since the 1990s, the EU-27 countries have lost $12 \%$ of their agricultural area, largely due to the spreading of urban and industrial areas [31]. In addition, agricultural land is being drastically concentrated down to fewer and bigger farms, land speculation has increased agricultural land prices, and old farmers are often not being replaced by a new generation of farmers. In this context of highly unequal land distribution and difficult land access, a growing number of movements and grassroots initiatives have joined forces to counter the growing trend of land grabbing and land restructuring. Since 2012, the European Access to Land Network has worked together with around 15 organisations to promote access to land for agroecological farming and transition, and generational renewal [31,32]. Among them are Terre de liens (France), Eco Ruralis (Romania), Xarxa de Custodia del Territori, Rurbans, Terra Franca (Catalonia, Spain), Terre-en-vue, De Landgenoten (Belgium), Soil Association, Real Farming Trust, Biodynamic Land Trust (United Kingdom), Regionalwert AG, BioBoden Genossenschaft, Kulturland eG (Germany), AIAB Lazio, Campi aperti - Accesso alla terra (Italy) and Viva Sol (Lithuania). Dingkuhn and colleagues [30] also mention Toekomstboeren in the Netherlands.

Seeds are considered an essential resource for agroecology, because local peasant varieties are important to increase the autonomy, independence and resilience of agricultural systems. In Europe, numerous NGOs support ancient and rustic seed production and exchange, as well as seed banks, such as the Réseau Semences Paysannes and Kokopelli in France, Red de Semillas in Spain, Eco Ruralis in Romania, Arche Noah in Austria, Germany and Switzerland, and Rete Semi Rurali in Italy. All those initiatives are active on different levels, both nationally and transnationally, in lobbying against GM crops, as well as defending the right to preserve ancient variety of seeds by keeping them free of patents.

\subsection{Networks}

Cooperation is at the heart of agroecology, and several initiatives have begun to create networks to foster the cooperation and collaboration between stakeholders in the food system. Some networks are urban, regional or national, while others have a European scope, and they work on various themes. For example, some are networks of farmers or researchers who focus on practices and science, some work on political campaigning and advocacy, some work on specific practice-related issues such as 
seed saving or agroforestry, others are associations of individuals who pool their experiences and competencies together to offer training and consultancy services. The common aims for these networks are to support research and education, to share knowledge and practices (often horizontally), and to promote agroecology along the entire food chain and in larger society.

Several countries have a national organisation that aims to create a network around agroecology in their national contexts. For example, Spain has the Spanish Society for Ecological Agriculture, Greece has the Agroecological Network of Greece, the United Kingdom has Agricology, Belgium has Agroecology in Action and the Interdisciplinary Agroecology Research Group of the FNRS, Romania has Eco Ruralis, and Hungary has the Agroecology Network Hungary. At the European level, there is Agroecology Europe, an association started in 2016. Central to its approach is the consideration of agroecology as a science, a practice and a social movement and thus it aims to foster interactions between actors from a variety of disciplines (professionals, practitioners, citizens, researches, policy-makers) to amplify agroecology [7].

More European-wide network examples are Arc2020 and the AgroEco Cities European Network. Arc2020 is a multi-stakeholder platform involving over 150 civil society networks and organisations (from $22 \mathrm{EU}$ Member States) all working on issues affected by the EU's Common Agricultural Policy [33]. Arc2020 promotes agroecology by addressing a diverse set of issues, ranging from nature protection, human health and animal welfare, to development cooperation, global justice and climate change, as well as those of conventional and organic farmers and rural development networks.

The AgroEco Cities European Network vision is to form a broadly interconnected partnership among European cities to the implementation of a productive and sustainable agricultural model in their influence areas [34]. It aims to work with European cities (at the moment there are 12), on themes such as sustainable production systems, regionalised markets, local food consumption, food sovereignty and security, as well as to promote innovation and mobilise external resources.

\section{Agriculture, Agroecological Territories, and Food Systems}

The modern agri-food system has distanced producers and consumers from each other by creating long supply chains. While in the conventional food system there is often a lack of trust between producers and consumers, certification schemes were developed as a way to establish trust in the product's quality. However, now there are multiple agroecological approaches that move toward a closer relationship between producers and consumers, and that foster the valuation of agricultural produce without the need for official and formal certification.

\subsection{Community Supported Agriculture}

Community Supported Agriculture (CSA) is strongly connected to agroecology as it brings a closer consumer-farmer connection by having at the maximum one intermediary in the supply chain. The first European CSA started in Switzerland in the 1970s and began spreading throughout Europe in the early 2000s. It was quickly very successful in France with the AMAP (Association for the Maintenance of a Peasant Agriculture) system, which has inspired many pioneer CSA projects in other European countries. However, the French AMAP system is still the most organised and developed of all CSA systems in Europe.

According to [31] investigating on CSAs in over 22 European countries, CSAs already feed around 1 million consumers in Europe. They are mainly initiated by consumers (41\%), followed by farmers $(33 \%)$ and a combination of both (18\%). A large majority of them (94\%) focus on vegetable production, but they are increasingly covering a wider range of products such as fruits, eggs, meat, honey, dairy products and bread. CSA farmers are often independent or have a small business status, but only $22 \%$ of them manage to get their full income from farming.

In many countries, CSAs tend to organise countrywide with a national network, or regionally, like in Belgium (Le Réseau des GASAP and CSA Netwerk) and Switzerland (FRACP, Conprobio and Verband Regionale Vertragslandwirtschaft) where each linguistic region has its own network. 
Among the countries with national networks, there is France (AMAP), the United Kingdom (CSA Network), Germany (Netzwerk Solidarische Landwirtschaft), Hungary (Közösségi Kisgazdaságok Szövetsége-KöKiSz, the Alliance of Small-Scale CSA Farms in Hungary), Ireland (CSA Network Ireland), Italy (Solidarity Purchase Groups, called Gruppi di Acquisto Solidale-GAS), Norway (Oikos-Organic Norway), Romania (Asociația Pentru Susținerea Agriculturii Țărănești), and Sweden (Andelsjordbruk Sverige).

\subsection{Agroecological Territories}

Italy and Spain contain two examples of territorial transition towards agroecology. In both examples, the initial transition to a sustainable farming model on a large territory scale has resulted in the involvement of many different stakeholders in the area that are engaged in very diverse activities. In Italy, the agroecological transition can be well represented by the development of 'Bio-districts' [35]. Bio-districts are territories characterised by a strong inter-linkage between actors, such as farmers, consumers, the touristic sector, municipalities, regional parks, and other local associations to support regional rural development. Their goals are to provide employment, decrease abandonment of rural areas, foster the production of traditional products, protect biodiversity and landscapes, and develop eco-tourism. Currently, there are 11 bio-districts in Italy, and a few in greater Europe.

In Spain, the agroecological initiative taking place in the 'Gallecs' agricultural and forestry territory on the outskirts of Barcelona is an example of agroecological transition on a regional scale [36]. There, a new agricultural model, developed through a participatory process, has allowed for the continuity of activities based on traditional farming and for the harmony of economic and environmental sustainability, despite town-planning pressure. The driving forces behind the initiative have been the proximity of a local consumer market, social demand for food quality and food safety, new leisure activities, environmental education, and agrotourism.

Further examples exist from the Netherlands where municipalities, towns, or provinces support the development of agroecology, e.g., the town of Almere, the province of Groningen, the municipality of Ede with its 'food valley', and the Lingezegen Park [30].

\subsection{Agroecological Produce and Certification}

While a closer relationship between producers and consumers has already been mentioned in the section on CSA, Participatory Guarantee Systems (PGS) are another avenue to both add value to agroecological food and to create relationships between farmers, consumers and other stakeholders in the agri-food system. PGS are quality assurance systems that are based on active participation of stakeholders to certify local products, strengthen social networks, and allow for knowledge exchange. Proven to be an affordable alternative to third-party certification, they are particularly appropriate for small-scale farmers who want to access local markets for organic or agroecological produced food [37,38]. Organics International lists twelve PGS initiatives in Europe: four in Spain, four in Italy, two in Belgium, one in Hungary and one in France [38]. Although the presence of PGS in Europe is still rather low compared to other parts of the world, its number has increased in the last years [39]. Nature et Progrès, founded in France in 1964, was one of the first PGS worldwide. However, no PGS in Europe has yet been recognised by local authorities.

In contrast to the peer-reviewed certification through PGS, there are some associations that have introduced labels for specific products that comply with their standards, which require the implementation of agroecological practices and are controlled by an accredited and independent body (third-party certification). These labels mainly focus on one aspect (e.g., promoting pollinator-friendly systems) in the agricultural production system. For example, 'Bee Friendly' is the name of the label of an association with the same name, and was created by beekeeper organizations from France, Italy and Germany [40]. Currently Bee-friendly specifications are developed on three sectors (viticulture, fruits and vegetables, dairy products) and include, for example, the prohibition of genetically modified organisms and neonicotinoids and the setup of areas of biodiversity conservation. 'Terra Vitis' is 
another possibility for vinegrowers-winemakers to demonstrate commitment to sustainability by becoming certified to a set of production specifications and highlighting the importance of social responsibility [41]. The French Ministry of Agriculture has recognized both the Bee Friendly and the Terra Vitis labels as environmental certification. Another example is the 'Haymilk' traditional specialty guaranteed label, which even received an EU regulation [42]. The label requires at least $75 \%$ roughage and prohibits the use of fermented fodder and genetically modified feed. Haymilk (Heumilch/Haymilk/Latte fieno/Lait de foin/Leche de heno) is found in Austria, Germany, Italy and Switzerland.

Labels focusing on selected aspects of agroecology (e.g., Bee Friendly, Terra Vitis, Haymilk) and Participatory Guarantee Systems are some of the options farmers have to certify their products. In agroecology, no specific indications exist so far for any 'agroecological' labels. However, first initiatives are on the way in France to discuss and define which agroecological practices and principles are already found or should be included in the production rules of quality labels [43].

Other examples of agroecological produce and food-related initiatives in Germany, Greece, Italy, the UK, Ireland, Poland, France and Spain are described [44,45]. Moraine and colleagues [46] also show different examples of agroecological farms in Europe. They gathered a variety of agroecological initiatives from Ireland, the UK, Belgium Austria, France, Portugal, Spain, Denmark and Romania. These initiatives run the gamut from grazing systems to supply chains, and illuminate just how broad agroecology in Europe is. Other examples from the Netherlands are presented in [30]. There are surely many more examples all over Europe that are not yet documented in literature.

\section{Towards Recognition of Agroecology in Europe}

Agroecology has taken a growing importance in the European debate on the agri-food system. This has been directly linked to its increasing recognition in various fields, including stakeholders from the scientific, political, social and economic sectors.

\subsection{Scientific Recognition}

Research about agroecology in Europe is well-developed and structured, as numerous institutions already have agroecology departments, institutes and/or research groups. Relatedly, the number of publications has significantly increased over the last twenty years [4]. Still, most of the research bodies and universities dealing with agroecology are located in the western and northern parts of Europe. This might be due to the fact that agroecology and its different interpretations are far less used and developed in Eastern Europe.

While there are research bodies that specifically deal with agroecology, there are others where agroecology is just a component of a broader range of research themes. Thus, the outcomes of the research on agroecology can be biased, depending on the approach each agroecology department has. Often, the approach tends to be 'unidisciplinary' and rather oriented towards agronomy and practices, but it may also be more transdisciplinary, addressing the holistic nature that characterises agroecology.

Moreover, a majority of the agroecology master and PhD programmes are taught in English, few in Spanish, or French, and are also mostly located in the western and northern parts of Europe. Not only can the language affect the approach to agroecology, but more importantly, the language skills that are required can close the door to agroecology higher education to many knowledgeable and competent students who are not fluent enough to study in either English, Spanish or French.

\subsection{Political Recognition}

Agroecology in Europe includes many bottom-up initiatives, such as farmers working together for better practices and networks between research institutes and social movements. However, to scale agroecology up and to further integrate it within the main regime of farming and food systems, it needs stronger political support and a regulatory framework, both at national and European levels. The rapid development of GIEEs in France after the integration of agroecology to the Rural Codex 
proves that such regulation can be an important catalyst for its development. At the EU level, even if the agri-environment measures of the CAP encourage more sustainable practices, there is not yet specific integration of, or support for, agroecology, but discussion has begun with the start of the next CAP reform negotiations.

\subsection{Social Recognition}

Agroecology is also increasingly serving the scope of national, European and international NGOs for lobbying for food and agrarian policy reforms within the political arena, and for developing more sustainable food systems with local stakeholders. As networks join different actors at multiple levels, agroecology is gaining more visibility. These networks work on a wide range of topics, and many of them are young networks that are still developing and consolidating. There is a huge potential for cooperation and synergies among them, but it remains to be seen whether they will be able to not only bring stakeholders together and sustain their activities, but also to bridge the gap between the local, regional, national and European scales, and between different stakeholder groups.

\section{Conclusions}

There is increasing evidence and many examples for the current trend of expansion and evolution of agroecology throughout Europe. As a science, movement, and a practice, agroecology is flexible, which allows many to embrace the concept with many different means of application. However, this flexibility can also cause fragmentation and a lack of joint participation from the diverse actors actively supporting its expansion. Academic agroecology is still largely disconnected from the agroecology movement. There is ongoing discussion between these two 'worlds' showing this (one of the authors is involved in this), and also that there are few common actions or research for example. In Europe, the scientific component of agroecology remains the most recognised so far, compared to the Global South, where practice and movements have historically been the leading forces and are still mostly dominant. In academia, there is no strong consensus of what education in agroecology is. Additionally, there exists a geographic unbalance in academics and research, which is mainly found in the west and north, and is dominated by the English language. While academic institutions are increasingly using the term agroecology for their programmes, this may not be the case for practical institutions, such as farmers schools.

Partially because there does not exist any agroecology label, there are few ways to communicate the value of agroecologically produced food. Currently, the only proxy is the label given to organically produced foods. While there are alternative food systems that have an agroecological approach, such as CSAs, they vary greatly in their agricultural and social commitment to agroecology. It can be expected that there exist many more initiatives, networks, associations in Europe that deal with agroecology, but that do not use the term explicitly, and thus are not visible within this framework.

In order to support the farms' transition to agroecology, as well as the growth of other bottom-up agroecology initiatives for farming and development of sustainable food systems, stakeholders must join forces to obtain political support, at both the national and European levels.

Acknowledgments: Thanks to Jan Moudry, who provided information about the Czech Republic, and Paola Migliorini for comments on the manuscript. We also thank those interviewed for giving us more insight into agroecology in some countries in Europe. Moreover, we thank E.L. Dingkuhn, A. Marchetti, B. Flipo, P. Parros, and J. van den Heuvel who analysed agroecology in the Netherlands extra for this paper.

Author Contributions: Alexander Wezel is the main writer of this paper. Julia Goette compiled Section 5.3 on agroecological produce and certification. Elisabeth Lagneaux focused on the access to land and on Community Supported Agriculture. Gloria Passuello was responsible for Section 4.2 on political actions and social movements and also contributed to part 4.3 and 5.2 of the paper. Erica Reisman focused on the research and education 3.1 and 3.2 sections of the paper, and also edited the paper, and gave it a final proofread. Christophe Rodier focused on the networks section and contributed to Section 5.2. Grégoire Turpin focused on the academia and contributed also to the Sections 3.3 and 4.3 .

Conflicts of Interest: The authors declare no conflict of interest. 


\section{References}

1. Wezel, A.; Soldat, V. A quantitative and qualitative historical analysis of the scientific discipline agroecology. Int. J. Agric. Sustain. 2009, 7, 3-18. [CrossRef]

2. Wezel, A.; Bellon, S.; Doré, T.; Francis, C.; Vallod, D.; David, C. Agroecology as a science, a movement and a practice. Agron. Sustain. Dev. 2009, 29, 503-515. [CrossRef]

3. OEP (Osservatorio Europeo del Paesaggio). The various approaches of agro-ecology in the different countries. Synthesis of the national reports Austria-France-Italy-Lithuania-Slovenia. Euro-EducATES, 2017. Available online: http:/ / www.euroeducates.eu/medias / files/oep-o1-synthesis-of-national-reports-en-17-03-22.pdf (accessed on 5 November 2017).

4. Nicot, R. Les Réseaux Européens D'acteurs de la Recherche et de la Formation en Agroécologie. Master's Thesis, Université de Paris-Est Marne-la-Vallée, Paris, France, 2017.

5. ECVC (European Coordination Via Campesina). Agroecology_Environment. 2017. Available online: http:/ / www.eurovia.org/main-issue/agroecology-environment/ (accessed on 10 January 2018).

6. FOEE (Friend of the Earth Europe). Feeding Europe: Food Sovereignty and Agro-Ecology. 2014. Available online: http:/ / www.foeeurope.org/feeding-europe-agro-ecology-280314 (accessed on 5 November 2017).

7. Agroecology Europe. Our Approach. 2017. Available online: http://www.agroecology-europe.org/ourapproach/ (accessed on 12 December 2017).

8. Agroecology in Action. Agroecology in Action Forum 2016. Available online: http:/ /agroecologyinaction. be/spip.php?rubrique1 (accessed on 5 November 2017).

9. FAO. Regional Symposium on Agroecology for Sustainable Agriculture and Food Systems for Europe and Central Asia, Budapest, Hungary, 23-25 November 2016; 2018. Available online: http://www.fao.org/ europe/events/detail-events/en/c/429132/ (accessed on 10 January 2018).

10. Agroecology Europe. Agroecology Europe Forum. 2017. Available online: http://www.agroecology-europe. org/agroecology-forum-2017/ (accessed on 12 December 2017).

11. FAO. International Symposium on Agroecology for Food Security and Nutrition 2014.2018. Available online: http:/ / www.fao.org/about/meetings/afns/en/?_scoop_post=2964fe60-3d9a-11e4-daf690b11c3d2b20\&_scoop_topic=2055030 (accessed on 15 January 2018).

12. Elzen, B.; Augustyn, A.; Barbier, M.; van Mierlo, B. AgroEcological Transitions: Changes and Breakthroughs in the Making; Wageningen University \& Research: Wageningen, The Netherlands, 2017.

13. EAKEN. European Agroecology Knowledge Exchange Network. 2017. Available online: http://www. eurovia.org/eaken/ (accessed on 12 January 2018).

14. Urgenci. CSAct! 2017. Available online: https://urgenci.net/csact/ (accessed on 10 November 2017).

15. Ministre de L'AGRICULTURE, de L'AGROALIMENTAIRE et de la Forêt. Le Projet Agro-Écologique en France. 2017. Available online: http://agriculture.gouv.fr/agriculture-et-foret/projet-agro-ecologique (accessed on 12 January 2018).

16. Légifrance: Code Rural et de la Pêche Maritime Livre Préliminaire: Objectifs de la Politique en Faveur de L'agriculture, de L'alimentation et de la Pêche Maritime. Available online: https: / www.legifrance.gouv.fr/ affichCode.do?cidTexte=LEGITEXT000006071367 (accessed on 12 December 2017).

17. Ministère de l'Agriculture et de l'Alimentation. Les groupements D'intérêt Économique et Environnemental (GIEE). 2017. Available online: http://agriculture.gouv.fr/les-groupements-dinteret-economique-etenvironnemental-giee (accessed on 10 January 2018).

18. Arc2020. Czech Agriculture-Using CAP for Agroecology? 2015. Available online: http://www.arc2020.eu/ is-czech-agriculture-starting-to-use-cap-for-agroecology / (accessed on 10 January 2018).

19. ECVC (European Coordination Via Campesina). Members. 2017. Available online: http://www.eurovia. org/about/members / (accessed on 10 November 2017).

20. FIAN International: Who We Are. 2017. Available online: http://www.fian.org/who-we-are/who-we-are/ (accessed on 5 November 2017).

21. FOEE (Friends of the Earth Europe). About US. 2017. Available online: http://www.foeeurope.org/about (accessed on 5 November 2017).

22. IFOAM EU Group. Vision \& Strategy until 2030. 2018. Available online: http://www.ifoam-eu.org/en/ what-we-do/vision-strategy-until-2030 (accessed on 10 January 2018). 
23. Cultivate! Who We Are. 2018. Available online: http://www.cultivatecollective.org/who-we-are/ (accessed on 15 January 2018).

24. Slow Food: About Us. 2015. Available online: https://www.slowfood.com/about-us/ (accessed on 15 November 2017).

25. Slow Food. Slow Food Foundation for Biodiversity: Italian Presidia. 2017. Available online: https://www. fondazioneslowfood.com/en/what-we-do/slow-food-presidia/the-project/italian-presidia/ (accessed on 15 November 2017).

26. Slow Food. The Agriculture We Want to See. 2018. Available online: https://www.slowfood.com/ sloweurope/en/topics/agriculture/ (accessed on 10 January 2018).

27. Kisléptékû. About Kisléptékû. Available online: http://www.kisleptek.hu/information_in_english (accessed on 10 November 2017).

28. Butterfly Complex Regional Development: About Pro-Ratatouille. Available online: http://www.bffd.hu/ pro-rataouille-program/about-pro-ratatouille (accessed on 10 November 2017).

29. Voedsel Anders. Towards Fair and Sustainable Food Systems. 2017. Available online: https://www. voedselanders.nl/towards-fair-and-sustainable-food-systems (accessed on 10 November 2017).

30. Dingkuhn, E.L.; Marchetti, A.; Flipo, B.; Parros, P.; van den Heuvel, J. Agroecology in the Netherlands. Overview and Development Trends. Wageningen University: Wageningen, The Netherlands, Unpublished work, 2017; 19p.

31. Access to Land and Urgenci. Access to Land and Community Supported Agriculture Stories from Europe. 2017. Available online: https:/ / urgenci.net/wp-content/uploads/2017/06/A2L_Pages.pdf (accessed on 12 December 2017).

32. Access to Land. Our Network. 2018. Available online: http://www.accesstoland.eu/-Our-network(accessed on 15 January 2018).

33. Arc2020. About Arc2020. 2017. Available online: http://www.arc2020.eu/about-arc2020/ (accessed on 10 November 2017).

34. AgroEco Cities European Network. Available online: http://www.agroecocities.eu (accessed on 10 December 2017).

35. Basile, S.; Nicoletti, D.; Paladino, A. Report on the Approach of Agro-Ecology in Italy; Osservatorio Europeo del Paesaggio: Padula, Italy, 2015; 32p.

36. Generalitat de Catalunya and Consorci de Gallecs. L'espai Rural. 2018. Available online: http://www. espairuralgallecs.cat/ca/que-es/1-espai-rural-3/index.htm (accessed on 15 January 2018).

37. Bellon, S.; Lamine, C.; Olivier, G.; Abreu, L.S.D. The relationships between organic farming and agroecology. In Proceedings of the Organic is Life, Knowledge for Tomorrow Conference, Namyangju, Korea, 28 September-1 October 2011. Available online: https:/ / www.alice.cnptia.embrapa.br/handle/doc/917959 (accessed on 12 December 2017).

38. IFOAM: Participatory Guarantee Systems Worldwide. 2017. Available online: https://www.ifoam.bio/en/ pgs-maps (accessed on 10 November 2017).

39. Willer, H.; Lernoud, J. The World of Organic Agriculture. Statistics and Emerging Trends 2016. Research Institute of Organic Agriculture FiBL and IFOAM Organics International, 2016; 340p, Available online: https:/ / shop.fibl.org/chfr/mwdownloads/download/link/id/747/ (accessed on 10 November 2017).

40. Bee Friendly. Available online: http:/ / www.certifiedbeefriendly.org/wp-content/uploads/2014/02/Bee_ Friendly_dossier_de_presse.pdf (accessed on 12 December 2017).

41. Terra Vitis. Presentation of Terra Vitis. Available online: http://terravitis.com/presentation/?lang=en (accessed on 12 December 2017).

42. EUR-LEX. Commission Implementing Regulation (EU) 2016/304 of 2 March 2016 Entering a Name in the Register of Traditional Specialities Guaranteed (Heumilch/Haymilk/Latte fieno/Lait de foin/Leche de heno (TSG). 2016. Available online: http:/ / eur-lex.europa.eu/eli/reg_impl/2016/304/oj (accessed on 15 January 2018).

43. Migliorini, P.; Wezel, A. Converging and diverging principles and practices of organic agriculture regulations and agroecology. A review. Agron. Sustain. Dev. 2017, 37, 63. [CrossRef]

44. Arc2020; Friends of the Earth Europe. Transitioning towards Agroecology. Using the CAP to Bulld New Food Systems. Ar2020: Berlin, Germany, 2015; 25p. Available online: http:/ /www.arc2020.eu/innovativenew-brochure-on-transitioning-towards-agroecology-launched/ (accessed on 10 January 2018). 
45. Inkota; Oxfam; Misereor. Better and Different! Transforming Food Systems through Agroecology. 2017. Available online: https://www.rosalux.de/fileadmin/rls_uploads/pdfs/sonst_publikationen/ BetterAndDifferent_TransformingFoodSystems_pdf.pdf (accessed on 15 November 2017).

46. Moraine, M.; Lumbroso, S.; Poux, X. A Comprehensive Outlook on the Diversity of Agroecological Initiatives in Europe. EFNCP; IDDRI, 2016. Available online: http://www.efncp.org/download/Plaquette_AEinitiatives_VF_June_light.pdf (accessed on 10 January 2018).

(c) ( 